\title{
A saracura: ritmos sociais e temporalidades da metrópole do café (1890-1920)
}

PauloKoguruma

Doutorando FFLCH-USP

RESUMO

Este artigo discute alguns aspectos doprocesso de urbanização da cidade de Sáo Paulo entre os anos de 1890 e 1920. Em especial, as singularidades da configuração de um ambiente cosmopolita peculiar, onde se nota, sob a face europeizada e moderna de Sáo Paulo, a existência de outros ritmos sociaise temporalidades. Trata-se de uma reflexão sobre as especificidades do processo de urbanização da Paulicéia em que se é possível perceber as múltiplas tensóes que perpassavam a configuração de uma paisagem caracterizada pelo movimento das ruas, bem com pelas instabilidades dos seus padróes sociais e culturais.

Palavras-Chaves: São Paulo; Modernidade; Temporalidades; Urbamização.

\section{Abstract}

This article analises some features of urban development process of city of São Paulo in the years between 1890 and 1920. Especially, the pecularities of the configuration of one singular cosmopolitan atmosphere in the city, in wich it could to be noted that under the europeian and modern face of Sáo Paulo had otbers social rithms and an multiplicity of times. It's one reflection about de pecularities of urban development process of the "Paulicéia", in wich it's possible to note the multiplicity of tensions that to pass by the configuration of one urban scene characterized by the bustle of streets and instabilities of social and cultural shapes.

Keywords: São Paulo; Modernity; Multiplicity of Times; Urban Development. 
Acidade de São Paulo é uma capital cosmopolita, onde ao antigo elemento nacional, ainda em maioria, se vieram misturar, numa indigesta confusão de raças e de civilizaçôes, outras gentes escumadas de todas as terras do mundo, desde a Grécia até oJapão.

Daía grande e natural instabilidade com que aqui se apresentam todos os usose costumes, sempre inclinados a revestir formas, ora extravagantes, ora ridículas, no seu desenvolvimento excessivamente rápido, de contínuo perturbadopor influênciasforasteiras. (Hilário Tácito, In Madame Pommery) ${ }^{1}$

Nos interstícios das narrativas de memorialistas, cronistase viajantes que tematizaram sobre a São Paulo dos finais do século passado e início deste, podemos entrever alguns elementos das diversas formas de sociabilidade que vicejavam sob a atmosfera européia e aburguesada que perpassava o seu tumultuário processo de urbanização. Essassociabilidades também participavam da configuração da fisionomia citadina, embora quase sempre fossem mal vistas pelas autoridades públicas, pelas elites dominantes e, às vezes, em função da begemonia e configuração dos saberes/poderes que regiam uma visáo de mundo afeita aos valores burgueses, também por um certo número de indivíduos pertencentes aos próprios setores subalternos da população citadina. Tratava-se da tensa configuração de um processo de urbanização contraditório, cujo desdobrartumultuário instituía na cidade "um multifacetado cosmopolitismo sócio-cultural gerando uma série de experiências cotidianas muito próprias e específicas, produtos do rápido crescimento urbano que colocava e recolocava novos choques, tensóes, confrontos e assimilaçóes em diversos setores da vida paulistana".

Defato, as inúmeras transformações econômicas, sociais, políticas e culturais que incidiam simultaneamente sobre a Paulicéia nascente não se limitaram somente à cópia dos parâmetros, modelos, instituiçóes e valores civilizatórios europeus ou, então, à cres- 
cente intensificação das relaçóes que ligavam o modo de vida dos babitantes da cidade aos fluxos e correntes da produçáo de produtos agrários para o mercado mundial. Em função da própria bistoricidade da configuração da cidade de São Paulo, isto é, em face das contradições, tensões, ambigüidades, indefiniçóes, enfim, das especificidades da constituição da urbe e da sociedade paulistana até aquele momento, a cidade de Sáo Paulo experimentou um cosmopolitismo conflituoso que sobrepôs no espaço urbano variados ritmos sociais, experiências vividas, visóes de mundo, temporalidades e elementos sócio-culturais, cujos encontros e desencontros geravam algumas das tensóes do processo de urbanizaçãoda cidade.

Assim, ao recordar-se da configuraçáo do bairro do Belenzinho por volta do ano de 1910, o memorialista Jacob Penteado menciona o "aborrecimento" dos moradores brancos daquele arrabalde com samba-batuque que era realizado pelos moradores negros na Rua Conselbeiro Cotegipe, em comemoração ao dia 13 de Maio. Cercado de preconceitos e estranbezas projetadas pelo olhar desse memorialista, de resto predominante numa sociedade em que a Abolição havia sido promulgada a menos de uma geração, esse evento organizado pelos negros do Belenzinbo foi descrito como um festival de promiscuidade.

Na rua Conselheiro Cotegipe (...) havia uns casebres, para dentro do alinhamento, com um terreiro e um vasto quintal, aosfundos, babitados por negros. Muitos deles, diziam-se ex-escravos. Na época, era dificil encontrar-se um negro velho que não se dissesse antigo escravo e veterano do Paraguai..

No dia 12 de maio, à véspera, portanto daquela data, à boca da noite, começavam a chegar negros que nem formiga. Vinham sozinbos ou em magotes, todos empunbando os mais variados instrumentos: bombos, chocallhos, pandeiros, atabaques, triângulos, maracas, tamborins, reque-reques, puítas, urucungos, marimbas, adufes eoutros, berdados, quiçá, dos seus ancestrais africanos. Surgiam tantos, que parecia incrivel coubessem naquele reduto. Seu chefe era o Barnabé(...)

Osamba de então era bem diferente do atual. Não passava de um exótico amálgama das numerosas danças regionais, da capoeira, do lundu, dojongo, do batuque, do cateretê etc. 
Depois dos comes-e-bebes, de muita cachaça ou quentão, os negros animavam-se, e aí começava o samba de roda. Sob o som infernal dos instrumentos de percussão, onde se destacava o toque surdo dos bombos e dos tambores, iniciava-se a noitada.

Formava-se uma roda no terreiro um dos parceiros pulava para o centro e começava a cantar, saracoteando-se todo:

'Oi, embaré, oi embará!

Balança que pesa oro não pode pesa metá!' (...)

O batuque ia esquentando. Em pouco tempo, vários pares pulavam no centro da roda, enquanto os demais batiam palmas, compassadamente. Eram movimentos alucinantes, desenfreados, contorsóes grotescas, sem ritmo nem graça, numa coreografia primitiva, onde as negras de bunda grande (negras iça) remexiam loucamente as cadeiras, lascivas e húbricas, entre tapas e beliscóes nas partes mais salientes. E o coro prosseguia (...)

Enessa toada varavam a noite. Nofim, nada mais se entendia. era uma sarabanda de mil diabos, um caia por cima do outro, numa promiscuidade danada. Muitos pares sumiam para ofundo do quintal, onde bavia umas bananeiras e pés de mamona. Na roda, ainda resistiam alguns, dançando, ou melbor, pulando alvoroçados, num insuportável intercâmbio de bodum.

E osamba continuava até odia raiar³.

Tratava-se de uma entre as inúmeras tensóes provocadas pelo adensamento de uma população diversificada na cidade de São Paulo, que convivia em espaços contíguos, em uma urbe que se expandia de modo tumultuário e desordenado. Contudo, nessa descrição de Penteado, além desse aspecto da convivência tensa da diversificada população paulistana, podemos entrever alguns dos elementos descritos por Maria Cristina Cortez Wissenbach sobre a comunidade dos escravos e forros e seu viver no mundo caipira da São Paulo na segunda metade do século XIX e, assim, assinalar a persistência de costumes e elementos sócio-culturais construídos sob autonomia relativa vivida pelos bomens e mulberes negros nos tempos do cativeiro a conviver com os olbares ambíguos marcados pelos preconceitos existentes entre as populações adventícias. Podemos perceber, nos interstícios da descriçãofeita por esse memorialista, as solidariedades e a liberdade relativa construídas e vividas pelos antigos escravos e pelos forros da cidade escravocrata ${ }^{4}$. Para além dos preconceitos contidos nessa descrição, subjazem, nitidamente, como um dos componentes de suas memórias de Penteado, ritmos sociais que marca- 
vam o "ajuntamento de negros" na cidade cosmopolita do início do século XX.

Os desdobramentos gerados pelas tensóes que marcavam a urbanização de São Paulo intensificaram-se à medida que se adentrava no século XX assinalando o conflituoso convívio sóciocultural no espaço urbano paulistano. Essas tensóes podiam ser notadas em certos pontos de sua paisagem onde os imigrantes estrangeiros e os nacionais se encontravam em busca da subsistência diária. Em seus escritos, Jacob Penteado recordou-se das atividadesdosmoradores pobres da cidade na coleta da alimentação diária em busca da sua sobrevivência nas margens do rio Tietê, no momento em que observava o trabalbo, os métodos e os costumes dasnegrasmariscadeiras, que classificava com sendo "primitivos", embora suas práticas não diferissem dos costumes dos imigrantes brancos ou dos caipiras'. Nas margens do Tietê, essas mulheres demonstravam o seu conbecimento acerca da ecologia dos matagais e espaços ruralizados do entorno paulistano, quando entravam nas águas do rio com as suas saias sungadas à maneira das lavadeiras da Várzea do Carmo, em busca de sua subsistência diária. Quiçá, fossem as mesmas mulberes que, no entanto, naquele momento, estavam a executar tarefas diferenciadas no seu improvisar cotidianodas lides de sobrevivência.

Asmargens do Tietê eram sombreadasporfrondosas árvores, onde pontificavam os ingàzeiros, que nosforneciam seus frutos, em forma de vagem, açucarados e deliciosos. Os córregos que nele deságuam, principalmenteo Tatuapé, também nos apresentavam rica fauna ictiológica. Mais acima, para os lados da Penha, o rio absorvia o Aricanduva. Era comum verem-se negras, quase nuas, saias sungadas, com uma bolsa de pano a tiracolo e peneira na mão, mariscando pela vegetação ribeirinha, apanbando peixes de toda sorte, por esse meio primitivo.

Apeneira era usada, outrossim, para pesca de camaróes, quando chegava o tempo da vazante, mormente nos fundo do Instituto, onde bavia regular correnteza. Era só empurrá-la pela relva acima, no leito do rio, e levantá-la rapidamente. Os camaróes surgiam no crivo, saltitando intensamente, como se fossem eximios acrobatas (...) ${ }^{6}$.

Podia-se notar, portanto, na fisionomia da urbe paulistana, locais onde a visibilidade dos ritmos sociais e temporalidades 
existentes da área urbana lembravam aspectos da cidade oitocentista. Além do chamado "Mercado Caipira", localizado na Várzea do Carmo, deveria haver no entorno citadino outros locais também conbecidos por essa alcunba. Nas primeiras décadas do século XX, existiam em São Paulo alguns locais nos bairrosmais afastados do centro da cidade onde transparecia um certo comércio miúdo movimentado pela população pobre do entorno citadino. Nesses espaços, diversos grupos de indivíduos provenientes das cercanias da cidade, que vinham para área urbana comercializar os excedentes de sua produção, encontravamse para o pernoite. Os chamados caipiras dormiam em certos pousos e ranchos existentes nesses bairros para no dia seguinte alcançarem as ruas mais próximas do núcleo central de São Paulo, espaços mais propícios à comercialização dos produtos excedentes de suas roças de subsistência ou extraídos das matas próximasda cidade:

Como em quase todas as cidades de então, eram comuns pousos e ranchos, onde se abrigavam os caipiras que vinbam de sítios distantes da Capital. Havia-os no Brás, junto à Chácara do Ferrão, no Lavapés, no Bexiga. No Belém, o pouso ficava à margem esquerda do Tietê, entre a Saboneira e a Rua Catumbi, em terras do Coronel Fortunato Goulart. Em 1910, ele as vendeu ao industrial Jorge Street, que ali instalou uma fábrica de tecidos e a Vila Maria Zélia, uma verdadeira pequena cidade industrial. Esse local era conbecido, também, por Mercadinbo dos Caipiras, que chegavam de Nazaré, Moji das Cruzes, Santa Isabel, Poá, Itaquaquecetuba, Guarulbos, Penba e Itaquera, rumo ao Mercado Central, e serviam-se de pouso para pernoitar, saindopela manhã, bem cedo. Alguns vinham a pé, mas a maioria servia-se de mulas com cangalbas, e até carros de bois. O pouso era constituído de barracóes, alugados a um mil réis por noite ${ }^{7}$.

Tratava-se do movimentado comércio de vinténs existente na cidade oitocentista, que persistia em marcar os ritmos sociais e as temporalidades vividos na São Paulo cosmopolitizada do início do século XX. Subjaziam sob a aparência aburguesada da urbe paulistana ritmos marcados por outras clivagens e outros fluxos, "que os documentos oficiais calavam, as elites desprezavam e os fotógrafos do início do século nem sempre priorizavam nas cenas de rua'" A crescente europeização do ambiente da cidade - 
aliás, tão bem observada e descrita pelos cronistas e memorialistas de antanbo - náo eliminou certos aspectos da urbe que já existiam na sociedade paulistana durante o período escravocrata, tais como aqueles os aspectos da economia informal construída pela comunidade dos escravos e forros na cidade oitocentista?.

Naquele momento, a "invisível" economia de subsistência da cidade, que fora o espaço social de sobrevivência dos setores subalternos da sociedade paulistana até então, adquiria novos elementos "que se transformaram ganbando maior diversificação com o surto da imigraçáo européia", de modo que as peculiaridades que configuravam a fisionomia da Paulicéia nascente manifestavam-se "menos nas residências de luxo e nas chaminés das fábricas e mais no próprio movimento de rua" . A grande maioria da população adventícia aderiu "a um tipo de organização informal da sobrevivência que, herdada da própria economia escravista, favorecia um pequeno comércio clandestino de gêneros de primeira necessidade e a troca de pequenos serviços entre vizinbanças contíguas. Ovolume da população intensificou a prática comercial, que entretanto dependia de improvisaçóes e se atinha nas ruas a pequenas trocas de vinténs e ao escambo, troca em espécie, como existia antes na pequena vila"11.

Tratava-se de um comércio de vinténs e ofertas de serviços variados, no qual se destacava a balbúrdia dos ambulantes a apregoar suasmercadorias ou seus serviços pelas suas ruas e esquinas da cidade. Assim, nos diversos logradouros públicos de Sáo Paulo podia se ouvir a algaravia de dialetos variados, em que se repetiam os pregóes daqueles que procuravam improvisar a sua sobrevivência diária na urbe paulistana:

Salvador peixeiro traz sobre os ombros um pau roliço de cujas pontas pendem dois cestos, a modo dos peixeiros da China: tainha (peixe ordinário), badejo, garoupa, robalo, camaróes. Um robalo grande (para casal e 04 fillhos e mais três empregadas) por 1.500, com camaróes de graça, para contrapêso ${ }^{12}$.

Vem outropeixeiro. É um caipira que andou pescando uma dúzia de bagres no Tietê. Está descalço, e traz os peixes enfiados pela guelra num cipó ${ }^{13}$.

OCastagnaro vendia 'castagna assada aoforno'. Oforno era um fogareiro conduzido em carrinho de mão, uma roda e duas hastes de suporte. As castanba iam sendo assadas, ele as tirava e enfiava 
num cordão, por meio de uma agulba. Juntando uma dúzia, amarrava na ponta de um pau ${ }^{14}$.

Escuta-se à distância um chiado estridente, como o canto das cigarras. Vem aumentado, e aparece o carro, com 'lenha bruta', vinda de Santo Amaro, puxado porjuntas de bois. Tange-os, ao lado, um caipira, descalço, de chapéu grande e lenço no pescoço, com uma vara de acicate ao ombro.

Comprando 'lenba bruta' paga-se quatro vezes o preço das carrocinbas de meio metro cúbico e recebe-se quantidade seis ou sete vezes maior [em relação a outro tipo de venda de lenba, já cortada e vendida por metro cúbico], despejada à calçada.

Daí a pouco aparece um preto descalço, de machado ao ombro, e se oferece para rachar e recolber:

Somando o preço da lenba ao que se pago ao preto rachador, dá diferença a favor do comprador dois e três mil réis ${ }^{15}$.

Um bomem traz às costas um jaca de taquara preso a tiracolo.

Pelos vãos largos do tecido passam cabeças de frangos.

- 'Quanto custa ofrango?'

- 'Mil e quinbentos'.

- 'Dou mil e duzentos'.

Discute-se, e ovendedor deixa pormil etrezentos. Afasta asmallhas dojaca com as mãos e tira um frango preto. A compradora sopralbe o pescoço: 'Esse não quero, porque tem pele preta'.

Obomem tira outro, o mais magro de todos: 'Não serve, pode irse embora'.

O bomem não quer ir. Discutem, discutem, e afinal fica um mais gordo pelos mil e trezentos (...) ${ }^{16}$.

Como esclarece Maria Inez Machado Borges Pinto, proliferavam em São Paulo as ocupações ligadas à economia "invisível”, que num contínuo improvisar de expedientes, multiplicavam-se pelas ruas e esquinas da cidade. De acordo com a arguta interpretaçấo dessa bistoriadora, múltiplas temporalidades e ritmos sociais podiam ser apreendidos no espaço urbano paulistano e não tão somente aquelas atividades da populaçấo cadenciadas pelo compasso do relógio ou pelo sinal de chamada das novas fábricas que entãosurgiam.

Geralmente, este exército de pessoas e minúsculos empreendimentos, na maioria das vezes, de base estritamente familiar, não estava computado nas estatísticas, nos recenseamentos ou registros oficiais, e nem mesmo nas análises acadêmicas de seus contemporâneos. Por este fato, apesar do grosso da população pobre, economicamente ativa subsistir trabalbando por conta 
própria e por meio de expedientes variados, à base de trabalbo não institucionalizado, muitas vezes intermitente, calcular o seu número aproximado é quase impossível; trata-se de um fenômeno que apesar de bem visível, praticamente é muito difícil de ser mensurado (...) inúmeros trabalbadores casuais, devido aos seus baixos ganbos e a sua aparência miserável, eram muitas vezes confundidos pelos contemporâneos com os vadios e mendigos, e a sua presença, como andarilbos em busca de trabalbo era motivo de inquietação para muitos moradores das regióes centrais por onde transitavam e costumavam fazer ponto, e de reclamação e intolerância dos barraqueiros e vendeiros dos dois mercados municipais. É provável que muitos elementos tidos como vagabundose presos porvadiagem fossem simplesmente trabalbadores itinerantes à cata de serviço(...) $)^{17}$.

Apopulação paulistana crescia multiplicando os expedientes para sobreviver em meio à pobreza que aumentava com o adensamento da populaçáo citadina. O universo de "estratégias" e "táticas" de sobrevivência, de papéis informais, de relações de vizinhança e familiares, de trocas sociais e culturais, enfim, de sociabilidades continuamente improvisadas-que for a construída pelos escravos, forros e brancos pobres durante a crise final da escravidão - só fez ampliar-se com a chegada de contingentes populacionais forasteiros. Naquele final de século XIX e início do XX, a movimentação nas ruas da cidade de São Paulofoi marcada pelas características do tenso convívio social que ocorria

(...) nas vizinbanças dos cortiços e dos novos bairros mais pobres que foram crescendo a partir da antiga Penba, entrada dos muares, para o novo mundo de oportunidades de pequenos negócios oferecidos pelas estações de trem. Um mundo não substituiu o outro mas foi sutilmente brotando um de dentro do outro, sob formas de convívio assíduo, às vezes de concorrência aberta, outras de preconceitos disfarçados, porém sobrepostos num entrelaçar de simultaneidades de tempos sociais que se cruzaram e se urdiram juntos na urbanização incipiente de Sáo Paulonopré-guerra. A diversidade étnica coincidia com a diversidade de nuanças de contratos de trabalbadores livres porém náo ainda assalariados. Operários se alternavam com trabalbadores temporários e estes por sua vez se multiplicavam numa multiplicidade de oficios diferenciados $^{18}$.

Assim, a cidade São Paulo transformara-se numa urbe que expressava um inusitado cosmopolitismo, já que seu ambiente 
citadino apresentava simultaneamente matizes europeizadose ares provincianos da cidade oitocentista. Tratava-se de um palco onde se podia observar um diversificado movimento de pessoas das mais variadas nacionalidades. O memorialistaJorge Americano assinala entre as suas reminiscências de São Paulo, não se uma certa dose de preconceitos e estereótipos, a diversidade dos atores sociais que percorriam as ruas da nascente "metrópole do café". Naquele momento, milhares indivíduos pobres pertencentes as mais diversas etnias faziam-se notar pelo improvisar seus expedientes de sobrevivência, ao mesmo tempo, que deixavam perceber seus diferentes costumes e tradiçóes:

Gente que a gente via

Portugueses degrandesbigodese lenços de Alcobaça, tomando rapé. Espanbóis de jaqueta e costeletas, um olho verde e o outro vasado. Bocas desdentadas de caipiras magrosvestidos de brim de algodão riscado.

Calmos alemães de olhos azuis, suorna testa e três rugas no toutiço gordo.

Japoneses espiando através de um risco entre as pálpebras àflor daface.

Mineiros de dorso arredondado, fumando cigarros de pallsa.

Italianos da Calábria, de guedelhas indomesticáveis, fumando cachimbosenormes.

Rarosjudeus de olbos de continhas azuis, um olho de cada lado donarizaguçado.

Dentes alvos reluzindo em ingênuas faces pretas.

Bocas rasgadas de orelha a orelha sob maçãs do rosto salientes, de nordestinos sem pescoço.

Ciganas lendo destinos, de tranças de azeviche, pele azeitonadae saias repolbudas.

Sírios de nuca batida e sobrancellhas em asa de urubu sobre narizes imensos.

Ilhéus de barbas em 'passa-piolhos', chapéus de abas grandese calças de veludo ${ }^{19}$.

Tratava-se dos diversificados atores sociais que se cruzavam na cidade dotando-a de uma fisionomia cosmopolita. A cidade de Sáo Paulo transformara-se numa encruzilhada onde se podia notar o tenso convívio de várias etnias. Configuravam-se na São Paulo da Belle Époque as especificidades dos encontros e desencontros da numerosa população que caracterizavam a nascente 
“metrópole do café”. Essas especificidades podiam ser percebidas mais no aspecto movimentado de suas ruas e esquinas do que nos estilos internacionais das fachadas das novas residências de luxo e altura das chaminés dasfábricas recém-construídas. Esses encontros e desencontros assinalavam o cosmopolitismo provinciano de uma cidade onde diferentes elementos sócio-culturais manifestavam-se simultaneamente. Ou seja, as tensóes do comvívio de uma população diversificada no solo paulistano permitiam que as características cosmopolitizadas e provincianas existentes na cidade aflorassem formando um panorama caleidoscópico. Na paisagem caótica da urbe paulistana, algumas das "estratégias" " "táticas" de sobrevivência dos setores subalternos da população assinalam a existência de práticas e crenças sócio-culturais que oscilavam entre as "ruralizadas" e as "urbanas". Essas práticas e crenças permeavam as experiências vividas pelos babitantes da cidade de São Paulo, sobretudo daqueles indivíduos pertencentes aos setores menosfavorecidos da sociedade.

Desse modo, algumas das ocorrências que ficaram registradas nasfontes policiais e/ou judiciais, bem como nos noticiários dos jornais paulistanos daquela época, revelam-nos os estranbamentos, familiaridades, ambigüidades, tensóes e conflitos existentes no diversificado comvívio social de uma populaçáo citadina, cujos indivíduos se cruzavam constantemente no burburinbo das suas ruas e esquinas. Nesse contexto da urbanização de Sáo Paulo podemos apreciar, algumas vezes, elementos relacionados a ritmos sociais e culturais diversificados, como por exemplo, a presença das práticas e crenças afro-brasileiras na cidade. Obistoriador Boris Fausto, ao pesquisar os Autos do Tribunal de Justiça do Estado de São Paulo, em seu estudo sobre a criminalidade no cotidiano da cidade, informa-nos que:

Jêronimo do Espírito Santo - o 'Sabará' era um mulato gaúcho, na casa dos 40 anos, que em 1908, ganhava a vida nas ruas próximas ao mercado central, vendendo raizes, peles e dentes de cobra. Em outros tempos, fora agente de polícia 'brigara muito, dera muita bordoada', mas sempre tinha se livrado de um processo, então nas ruas da 'cidade italiana', surgia como um personagem marginal, 'vestido de bombachas exageradíssimas, chapéu cinzento de abas largas, botas de couro pretas e grande 
faca à cinta'. Aopercorrer a Rua 25 de Março, um grupo de meninos italianos se póe a ridicularizá-lo chamando-o de caipira, 'negro, macumbeiro'. Sabará da uns tapas em um dos meninos, que vai chamar o pai em seu socorro. Opai agarra o vendedor ambulante pelo cavanhaque e desafia: 'seu negro, foi você que bateu em meu filho?'. A resposta é uma facada mortal ${ }^{o}$.

A diversidade de elementos que podemos apreciar nessa ocorrência criminal permite-nos apreender as tensóes ocasionadas pelo conviver social em uma cidade que apresentava diferentes clivagens e múltiplas experiências vividas pelas sua população. Naquilo que nos interessa neste artigo, essa fonte assinala que havia na cidade vendedores ambulantes de ervas e curandeiros que atendiam as diversas demandas mágico-religiosas dos muitos habitantes da população variegada da São Paulo daquele final de século XXX início de século XX. Ademais, do mesmo modo que os ervanários estabelecidos nos mercados citadinos, esses atores sociais eram quase sempre mal vistos pelas autoridades públicas e estigmatizados perante a população como difusores de costumes "supersticiosos", que contaminavam a paisagem higiênica e europeizada da Paulicéia nascente, embora aqueles que estavam encarregados de fiscalizá-los ou reprimi-los soubessem que muitos moradores paulistanos, inclusive, aqueles pertencentes às "famílias mais cultas", utilizavam-se de seus serviços.

Obotânico F.C. Hoebne, a se indagar sobre o que faziam os curandeiros da cidade de Sáo Paulo, informa-nos do "exotismo" da diversidade das práticas mágico-religiosas e crenças que permeavam o ambiente citadino nas primeiras décadas do século $X X$, bem como assinala o arraigamento das "superstiçóes" $e$ "crendices" existentes entre os moradores da cidade cosmopolita:

Se procurarmos sindicar da origem destas duas profissóes (ervanários e curandeiros) afins verificaremos que a sua bistória se confunde com aqueles dos 'Brabmanes'e 'Fakiris' da India, e com os 'Obeabs' ou 'Vudus' da África, perdendo-se no kaos místico dos séculos. A miscelânea a que se dedicam, mostra bem a sua origem híbrida e fins suspeitos a que se destinam ${ }^{21}$.

eque: 
O resultado de qualquer negócio náo depende da oferta e sim da procura. Se pois o povo ainda não chegou a um grau de adiantamento capaz de avaliar e compreender a nulidade dos amuletos, figas, rezase benzedeiras; semesmopessoas defamíliasmaiscultas muitas vezes procuram favas e figas contra quebranto e mau olhado, para dependurá-los ao pescoço dos seus herdeiros, e têm confiança em uma oração, por que razão haveríamos de censurar aspessoas que se dedicam a tal comércio? ${ }^{22}$

Ademais, no ano de 1907, ojornal Correio Paulistano, em sua coluna de Factos Diversos, admitia que se podia "viajar ao redor do mundo em Sáo Paulo”. Nessa pitoresca coluna, um articulista desse jornal deixava transparecer aspectos singulares da cidade. Tratava-se de uma descrição dos cenários e das paisagens que eram bastantes familiares aos antigos moradores da cidade e, muitas vezes, não apreciados pelas elites dominantes da sociedade paulistana, que para além da face europeizada da "metrópole do café”, deixavam à mostra a existência de ritmos sociais e de temporalidades que também regiam a vida cotidiana de sua população. A descrição apresentada pelojornal expunba um cenário do espaço urbano paulistano que se encontrava incrustado entre os belos edifícios públicos e as magníficas residências de luxo que surgiam na São Paulo de então. Tal cenário permite a apreensão da diversidade de elementos presentes na configuração da fisionomia peculiar de São Paulo, bem como assinala a complexidade bistórica do processo de urbanização tumultuário, em que se podia notar a coloração de diversos matizes sócios-culturais:

ASaracura

É um pedaço da África. As relíquias da pobre raça impellida pela civilização cosmopolita que invadiu a cidade, ao depois de 88, foi darallinaquelafurna.

Uma linha de casebres borda as margens do riacho.

O valle é fundo e estreito. Poças dagua esverdeada marcam os logares donde sabiu a argilla transformada em palacetes e residências de luxo.

Cabras soltas na estrada, pretinbos semi-nus fazendo gaiolas, chibarros de longa barba ao pé dos velbos de carapinha embranquecida e lábio grosso de que pende o cachimbo, dão áquelle recanto uns ares do Congo.

Allipae Antonio, cujas mandingas celebram os supersticiosos de Pinbeiros, de Santo Amaro, da várzea e até do Tabôa, pratica os 
seus mysterios e tange o urucungo, apoiando ao ventre rugoso e despido a cabaça resomanta.

As casas são pequenas; as portas baixas. Há pinturas enfumaçadas pelas paredes esburacadas. A mobilia, caixa vellbas e tóros de pau, sobre ser pobre, é sórdida.

E alli vão morrendo aos poucos - sacrificados pela própria liberdade que não souberam gosar, recosidos pelo álcool e estertorando nas angustias do brightismo que os dizima, eliminados pela elaboração antbropologica da nova raça paulista -os que vieram nos navios negreiros, que plantaram o café, que cevaram este solo de suor e lágrimas, accumulados alli, como o rebutalbo da cidade, no fundo lobrego de um valle ${ }^{23}$.

Assim, embora na maior parte das crônicas ou memórias que retratam a cidade do final do século passado e início do XX se quisesse projetar sobre o cenário paulistano as imagens de uma cidade modernizada, erguida de acordo com os padróes civilizados das sociedades d'além mar, a "sordidez" da pobreza vivida pelos ex-escravos nas adjacências do velho núcleo urbano lembravam os matizes da cidade oitocentista, descritas anteriormente por testemunhas tais como Saint-Hilarie ouJohm Mawe, cujas ano94 taçóes descrevem taperas escuras e casas de pau-a-pique com paredes que estavam sempre enfumaçadas pela lenba verde utilizada nos rústicos fogóes improvisados sobre pedras redondas no seu chão lamacento e esburacado ${ }^{24}$ ou, ainda, remete àqueles cenários que podiam ser encontrados na amplidão dos sertóes do interior do território brasileiro, tais como os de Itapicuru, no sertão Babia, cujas paisagens acham-se descritas na documentação pesquisada por Monica Dantas ${ }^{25}$.

Em paisagens que ainda mantinbam uma atmosfera que lembrava aspectos da cidade oitocentista, os "superticiosos" moradores "de Pinbeiros, de Santo Amaro, da várzea e até do Tabôa”, enfim, dos bairros distantes e das vilas da cidade cercanias da cidade, insistiam em procurar o velho mandingueiro "pae Antonio" fazendo surgir nas adjacências do antigo núcleo central de São Paulo, ante aos olbos daqueles que a imaginavam a Paulicéia nascente moldada em padróes de uma elegante cidade européia, um recanto do continente africano ou, então, o cenário maisfamiliar da cidade de São Paulo dos tempos da escravidão. Segundo asmemórias de um vellho morador do Bexiga, assinaladas por 
Maria Cristina Cortez Wissenbach em seu estudo sobre as sociabilidades e as práticas mágico-religiosas no Brasil, nessa região da Saracura - que fora um local que abrigara redutos de escravos fugidos, alforriados e libertos na velha cidade oitocentista - podia-se notar no início do século a convivência de negrose imigrantes: "Existe uma parte, até hoje, que fica entre a Rua Rocha, a Rua Una e a Marquês Leão, que a gente chamava de Saracura, onde se localizavam muitos negros e portugueses (...). No Saracura, não existia mulato, era tudo negro, aqueles negros bem pretos, todos descendentes de escravos (...). Eram todos descendentes de escravos, bonzinbos, amáveis (...)"26.

As crenças mágico-religiosas que permeavam a vida cotidiana da população podiam, portanto, ser notadas em diferentes locais da urbe paulistana. Tal como nos tempos da São Paulo de Mãe Conga e Maria D'Aruanda ${ }^{27}$ elas pontillhavam no dia-a-dia da população em manifestações que aconteciam em diversos pontos do espaço urbano. Conforme denunciava o Correio Paulistano pouco mais de um ano e meio antes da publicação da nota sobre "A Saracura”, numa notícia referente ao outro lado do núcleo central da cidade, já que se reportava a um acontecimento ocorrido nobairro do Braz, encontrava-se preso no Posto Policial da Imigração um casal de feiticeiros que estava aguardando o resultado do andamento do competente inquérito policial. Esse casal fora flagrado no momento em que atendia aqueles "incautos" cidadãos paulistanos, que “em busca de remédios para seus males”, procuravam sua residência:

Feiticeiros

Ocoronel Octaviano de Oliveira $3^{\circ}$. subdelegado do Braz, recebeu ba dias diversas dennuncias contra Joäo Manoel e Generosa Maria de Jesus, moradores á rua Visconde de Parnabyba, accusando-os da pratica de feitiçarias para illudir a confiança de grande $n^{\circ}$. de incautos que diariamente frequentava aquella casa, em busca de remédios para os seus males.

Em virtude dennuncias, aquela auctoridade procedeu a rigorosa busca na residencia dos feiticeiros, bontem ás 11 brs. da manbã, prendendo em flagrante delictoJoão Manoel e Generosa, na occasião em que davam consultas a grande $n^{\circ}$. de individuos.

Os feiticeiros foram recolbidos ao xadrez do posto policia da Immigração, sendo, a respeito, instaurado competente inquerito ${ }^{28}$. 
Podemos apreender por meio das descriçóes daquele “lobrego" vale do Saracura, onde "Pae Antonio" praticava suas mandingas, bem como pelas das "feitiçarias" que eram realizadas naquela residência do bairro do Brás, onde de João Manoel e Generosa realizavam suas consultas, que as práticas e as crenças mágico-religiosas medravam entre os habitantes da "metrópole do café”. Ojornal Correio Paulistano, menos de um mês depois de publicado o relato sobre "A Saracura", noticiava que bavia entre os moradores da cidade de São Paulo "superstiçóes" e "crendices" das maisvariadas. Entre as diversas ocorrênciasmencionadas pelo autor(es) da coluna de Factos Diversos podia-se notar que grassava entre a população da nascente cidade cosmopolita uma "onda de superstição" e "fanatismo religioso" que atestava a aderência dos moradores de São Paulo às tradiçóes músticas provenientes das mais diversas origens:

\section{Superstição}

Tivemos a pouco, uma pequena amostra da superstição que por abianda.

Entrou pela repartição da policia um sujeito a implorar que lhe dessem um pedaço de corda de um enforcado.

Agora é um crime, que vem levantar uma ponta do véu que encobre muita crendice, muita fé em agentes sobre-naturaes, em rezas e esconjuros: sobre o cadáver de Maria do Carmo, a assassinada da ruadas Flores, acharam-seoraçóes, amuletosparaliurarem o possuidor de perigos e tentaçóes.

Parece incrivel que em um meio adeantado como o nosso medre assim a crendice. A gente habituada ao scepticismo, a indifferença ou á cultura intellectual incompatível com afé cega e supersticiosa, mal pode comprehender a inopia espiritual, ao terrordo fanatismo ignorante, as praticas de charlatanismoe da feitiçaria que dominam uma facção notável de nosso povo.

E não é tão somente a plebe ignorante que se deixa vencer da crendice, que traz 'mascottes' e collecciona ferraduras.

Comprehende-se que seria indiscreto revelar segredos da 'gente boa', mas impóe-se ao bomem da sciencia um estudo dessa face interessante do espirito popular.

É curioso notar: na mesma occasiáo de apparecerem em S. Paulo certas cartas com oraçóes que deviam ser recitadas e enviadas a nove pessoas, sob pena de terriveis castigos, Zumar, o grande geographo da Arabia, noticiando o incremento da propaganda 
mulsumana na Ásia e no Sudão, narrava um caso precisamente idêntico observado por elle naquellas regióes.

Impóe-se ainda aos propagandistas da religião, aos mestres, aos paes, - reagir contra esse fundo supersticioso, terrivel berança procedente do berço da civilizaçáo pristina-a planura de Shumir e Accad -Esse fundo supersticioso torna capaz, em meio de uma grande cultura social o apparecimento do 'mormonismo', da 'Christiam Science', das feiticeiras da Nova Inglaterra, do demonismo de Paris e de St. Pierre da Martinica, e das seitas mais ou menos curiosas, extranbas e fanáticas que mesmo em S. Paulo vão criando raízes, sem responsabilidade definida e sem poderem dizer propriamente a que systema religioso pertencem ${ }^{29}$.

Acidade de Sáo Paulo apresentava, portanto, uma fisionomia cosmopolita peculiar, já que o seu acelerado e tumultuárioprocesso de urbanizaçãofizera surgir nas terras planaltinas uma cidade que apresentava um ambiente marcadoporinúmeras indefinições, ambigüidades, tensões, contradições e conflitos. Tinha-se a impressão de que São Paulo tornara-se um espaço “onde ao antigo elemento nacional, ainda em maioria, se vieram misturar, indigesta confusão de raças e de civilizações, outras gentes escumadas de todas as terras do mundo"-como menciona a citação da epígrafe deste artigo -, pois existiam na cidade de São Paulo diversos cenários e situaçóes que deixavam vislumbrar os encontros e desencontros de sua população. Havia na cidade espaços contíguos às áreas europeizadas do velbo núcleo urbano ou, então, aos bairros da elite paulistana, tais como Higienópolis e Campos Elísios, que apresentavam outros ritmos e temporalidades que estavam a reger os costumes e o cotidiano dos habitantes de São Paulo. Tratava-se da mescla das múltiplas temporalidades na sociedade paulistana que permitem assinalar "a grande e natural instabilidade com que aqui se apresentam todos os usos e costumes, sempre inclinados a revestir formas, ora extravagantes, ora ridículas, no seu desenvolvimento excessivamente rápido, de contínuo perturbadopor influênciasforasteiras.” 


\section{Notas}

${ }^{1}$ TÁCITO, Hilário. Mme. Pommery. Campinas, Editora Unicamp 1992, p. 138.

${ }^{2}$ MORAES, José Geraldo Vinci. As sonoridades paulistanas (A música popular na cidade de São Paulo - Final do séc. XIX ao início do séc. XX). Dissertação de Mestrado, São Paulo, Depto de História da PUC-SP, 1989, p. VII, mimeo.

${ }^{3}$ PENTEADO, Jacob. Belenzinbo, 1910 (Retrato de uma época). São Paulo, Livraria Martins Editora, 1962, pp. 215-218.

${ }^{4}$ WISSENBACH, Maria Cristina Cortez. Sombos Africanos, Vivências Ladinas. Escravos eforros no Município de São Paulo 1850-1880. Dissertação de Mestrado, Sáo Paulo, FFLCH/USP, 1989, pp. 73 e ss. mimeo.

${ }_{5}^{5}$ PENTEADO, Jacob. op. cit., p. 163-164.

${ }^{6}$ Idem,pp. 163.

${ }^{7}$ Ibidem, pp. 80-81.

${ }^{8}$ DIAS, Maria Odila Leite da Silva. “Prefácio". In PINTO, Maria InezMachado Borges. Cotidiano e Sobrevivência:A vida do Trabalbador Pobre na Cidade de São Paulo, 1890-1914. Sáo Paulo, EDUSP, 1994. p.14.

${ }^{9}$ DIAS, Maria Odila Leite da Silva. Quotidiano e Poder em São Paulo no século XIX. $2^{a}$ ed., São Paulo, Brasiliense, 1995, pp. 117-169 e também WISSENBACH, Maria Cristina Cortez. op. cit., pp. 42 e 80.

${ }^{10}$ DIAS, Maria Odila Leite da Silva. 'Prefácio". ImPINTO, Maria InezMachado Borges. op. cit., pp. 14-15.

${ }^{11}$ Idem, p. 20.

$98{ }^{12}$ AMERICANO, Jorge. São Paulo naquele tempo (1895-1915). São Paulo, Ediçóes Saraiva, 1957, p.113.

${ }^{13}$ Idem, p. 114.

${ }^{14}$ Idem, pp. 119-120.

${ }^{15} \mathrm{Idem}, \mathrm{p.121.}$

${ }^{16}$ Idem, pp. 121-122.

${ }^{17}$ PINTO, Maria Inez Machado Borges. op. cit., pp. 109-110 e 151-152.

${ }^{18}$ DIAS, Maria Odila Leite da Silva. op. cit., 1994, pp. 16-17.

${ }^{19}$ AMERICANO, Jorge. op. cit. p. 370.

${ }^{20}$ FAUSTO, Bóris. Crime e Cotidiano-a criminalidade em São Paulo (1880-1924). São Paulo, Brasiliense, 1984, p. 123.

${ }^{21}$ Apud. SANTOS, Carlos José Ferreira dos. A População Pobre Nacional na Cidade de Sáo Paulo - Virada do Século: 1890-1915. Dissertação de Mestrado, PUC-SP, mimeo, 1995, pp. 179, nota de fim n ${ }^{\circ}$ 50, capítulo II. HOEHNE. FC. O que Vendem os Hervanários da Cidade de São Paulo. Serviço Sanitário do Estado de Sáo Paulo/Casa Duprat, 1920, p. 23.

${ }^{22}$ Idem, pp. 14-15 e 146-147.

${ }^{23}$ Correio Paulistano, 09/10/1907.

${ }^{24}$ DIAS, Maria Odila Leite da Silva. op. cit., 1995, p.220.

${ }^{25}$ DANTAS, Mônica. “Moradores do Itapicuru, 1820-1890”. In DIAS, Maria Odila Leite da Silva. Forros e brancos pobres na sociedade colonial do Brasil, 1675-1835. In História General de America Latina, Unesco, vol. 03, cap. 14, (noprelo). 
${ }^{26}$ WISSENBACH, Maria Cristina Cortez. Ritos de Magia e Sobrevivência -Sociabilidades e práticas mágico-religiosas no Brasil (1890-1940). Tese de Doutorado, Sáo Paulo, FFLCH/USP, Depto. de História, 1997, p. 78.

${ }^{27}$ DIAS, Maria Odila Leite da Silva. op. cit., p. 162.

${ }^{28}$ Correio Paulistano, 20/01/1906.

${ }^{29}$ Correio Paulistano, 08/11/1907.

Artigo recebido em nov./98, aprovado em mar:/99 
